\title{
Telerehabilitation for Patients With Knee Osteoarthritis: A Focused Review of Technologies and Teleservices
}

\author{
MReza Naeemabadi ${ }^{*}$, MSc, BME; Hesam Fazlali ${ }^{2 *}$, MSc, BME; Samira Najafi ${ }^{3 *}$, MSc, BME; Birthe Dinesen ${ }^{1}$, PhD; \\ John Hansen ${ }^{4}, \mathrm{PhD}$

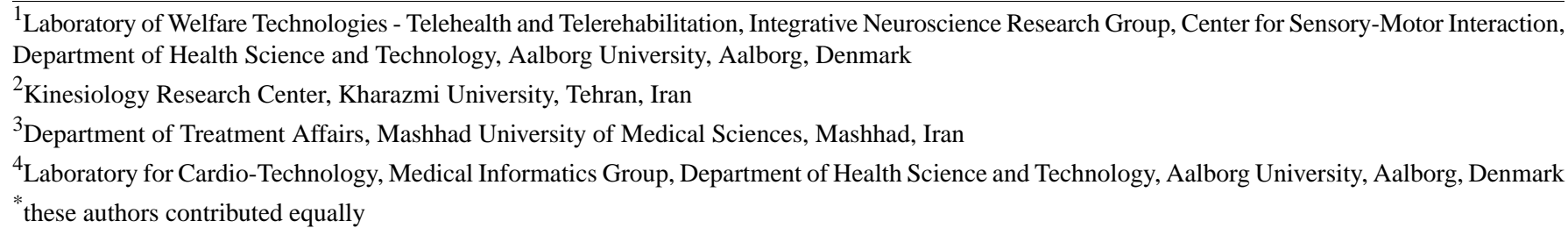

Corresponding Author:

MReza Naeemabadi, MSc, BME

Laboratory of Welfare Technologies - Telehealth and Telerehabilitation, Integrative Neuroscience Research Group, Center for Sensory-Motor Interaction

Department of Health Science and Technology

Aalborg University

Fredrik Bejars Vej 7D

Aalborg, 9220

Denmark

Phone: 4571348333

Email: mr.naeemabadi@gmail.com

\section{Abstract}

Background: Telerehabilitation programs are designed with the aim of improving the quality of services as well as overcoming existing limitations in terms of resource management and accessibility of services. This review will collect recent studies investigating telerehabilitation programs for patients with knee osteoarthritis while focusing on the technologies and services provided in the programs.

Objective: The main objective of this review is to identify and discuss the modes of service delivery and technologies in telerehabilitation programs for patients with knee osteoarthritis. The gaps, strengths, and weaknesses of programs will be discussed individually.

Methods: Studies published in English since 2000 were retrieved from the EMBASE, Scopus, Web of Science, Cumulative Index to Nursing and Allied Health Literature (CINAHL), PubMed, Physiotherapy Evidence Database (PEDro), and PsycINFO databases. The search words "telerehabilitation," "telehealth," "telemedicine," "teletherapy," and "ehealth" were combined with "knee" and "rehabilitation" to generate a data set of studies for screening and review. The final group of studies reviewed here includes those that implemented teletreatment for patients for at least 2 weeks of rehabilitation.

Results: In total, 1198 studies were screened, and the full text of 154 studies was reviewed. Of these, 38 studies were included, and data were extracted accordingly. Four modes of telerehabilitation service delivery were identified: phone-based, video-based, sensor-based, and expert system-based telerehabilitation. The intervention services provided in the studies included information, training, communication, monitoring, and tracking. Video-based telerehabilitation programs were frequently used. Among the identified services, information and educational material were introduced in only one-quarter of the studies.

Conclusions: Video-based telerehabilitation programs can be considered the best alternative solution to conventional treatment. This study shows that, in recent years, sensor-based solutions have also become more popular due to rapid developments in sensor technology. Nevertheless, communication and human-generated feedback remain as important as monitoring and intervention services.

(JMIR Biomed Eng 2020;5(1):e16991) doi: 10.2196/16991 


\section{KEYWORDS}

telemedicine; telerehabilitation; communication technologies; knee osteoarthritis; total knee replacement

\section{Introduction}

Osteoarthritis and chronic musculoskeletal disorders are considered the second most frequent medical condition and are the primary causes of physical disability and pain [1-4]. Knee osteoarthritis (KOA) among seniors is estimated at $10 \%$ and $13 \%$ in men and women, respectively [5]. Moreover, it has been reported that symptomatic KOA has doubled among women and tripled among men in the past 20 years [6]. Previous studies indicate that postsurgical physical rehabilitation is a crucial component of the recovery process [7] and that exercises and education are frequently recommended for patients with KOA [8].

Telecommunication technologies have been used to provide health care, monitoring, and rehabilitation services for patients who experience stroke [9], pulmonary disorders [10], COPD $[11,12]$, dermatological disorders [13], oral diseases [14], and musculoskeletal conditions $[15,16]$. Such technologies have also been used for remote consultations [17]. Using internet access, early telehomecare programs were implemented as a substitute for home care visits, and user perception and satisfaction were assessed and reported to be high $[18,19]$. Russell [20] introduced telerehabilitation as a means of augmenting traditional rehabilitation by employing telecommunication technologies that would provide services such as assessment, education, intervention, and interview. Previous studies indicated that telerehabilitation programs can provide better clinical services in rural and remote communities compared with conventional therapy $[21,22]$, as well as improve cost efficiency and resource management of the services [23-25] with high validity and reliability [26].

Previous studies have noted that a telerehabilitation program for KOA not only improves patients' quality of life [27] but also introduces a better functional recovery after arthroplasty in comparison to conventional therapy [28]. Sharareh et al [29] showed that providing a postoperative telerehabilitation program reduced the frequency of postoperative visits and increased patient satisfaction. Tousignant et al [30] and Chalupka et al [31] also indicated that home telerehabilitation enhanced accessibility to health care services and was as effective as conventional therapy.

Russell divided the technologies used for telerehabilitation into image-based, sensor-based, virtual environment, and virtual reality telerehabilitation [32]. Real-time video conferences were extensively used in physical telerehabilitation [33-36]. Giantomassi et al [37] indicated that current video game technologies could be used in physical rehabilitation. Several telerehabilitation programs have been developed using the Microsoft Kinect sensor [38-41] and the Nintendo Wii board [42-45]. Wearable sensors were also proposed as a means to facilitate a telerehabilitation program and monitor patient performance [46]. Moreover, Strecher [47] remarked that health care services could be delivered using decision-making algorithms and expert systems [48] over the internet. Rini et al
[49], using an expert system approach, adapted the face-to-face therapeutic intervention into an internet-based intervention. However, there is no clear vision of the strengths and weaknesses of each solution as well as the existing gaps and limitations of the presented solutions. In addition, there is a lack of focused reviews investigating the presented services as part of telerehabilitation programs.

Therefore, the main objective of this review was to identify and discuss the modes of service delivery and technologies used as a telerehabilitation program for patients with KOA in recent studies. The gaps, strengths, and weaknesses of programs were discussed individually.

\section{Methods}

\section{Search Strategy}

The search strategy was designed to identify relevant literature regarding telerehabilitation solutions for KOA while focusing on the technologies and services of the programs $[15,26,28,50]$. The literature search used here investigated studies that had implemented and evaluated a telerehabilitation program for patients with KOA using an experimental study design. The EMBASE, Scopus, Web of Science, CINAHL, PubMed, Physiotherapy Evidence Database (PEDro), and PsycINFO databases were searched. Searches were undertaken in March 2020, and comprised medical subject heading (MeSH) [51] terms and keyword search terms. The MeSH terms "telemedicine," "rehabilitation," and "knee" and keyword terms "telehealth," "ehealth," "teletherapy," "telecare," and "knee" were used. Moreover, both Telemedicine and e-Health and the Journal of Telemedicine and Telecare were searched independently using knee rehabilitation key search terms.

\section{Research Question}

The research questions of this review are the following: (1) Which modes of service delivery were used to establish a telerehabilitation program for patients with KOA? (2) What services were introduced by these programs? (3) What are the strengths and weaknesses of each solution?

\section{Inclusion Criteria}

Original English-language studies published from January 2000 to January 2020 were included if they fit the eligibility criteria, which were based on the PICOS framework [52].

\section{Participants}

Studies with adult participants (aged 18 years and above) with KOA were included. The studies in which participants' primary medical condition was not related to KOA (eg, stroke, upper limb disability, pulmonary disorders) were excluded.

\section{Intervention}

Only studies where telecommunication technology was employed as an interventional rehabilitation method in an experimental or observational study were included. The study intervention had to focus on knee pain management or knee 
rehabilitation for a period of at least two weeks via synchronous or asynchronous telerehabilitation (eg, phone, email, website report, videoconference, multimedia messages). Studies with insufficient technical explanations were excluded.

\section{Comparison}

All trials were included, whether they did or did not employ a control group.

\section{Study Design}

Any randomized controlled trial (RCT), quasi-RCT, non-RCT, controlled clinical trial, and pilot study designs, regardless of the blinding of the assessor, were included. Protocol manuscripts, review studies, abstracts, and guidelines were excluded.

\section{Data Collection}

According to the inclusion and exclusion criteria, a two-step study identification and data extraction process was used. Two authors (MRN and HF) independently screened the electronic search results. First, the retrieved studies were screened for eligibility based on their title and abstract. The full text of studies selected in the first stage was then reviewed and analyzed as a candidate for final inclusion. Any disagreement between the two authors was resolved through discussion between the authors; if necessary, a third author $(\mathrm{JH})$ was referred to for arbitration. Two authors (MRN and $\mathrm{SN}$ ) were responsible for data extraction from the included articles. The extracted items were study design, study population, medicinal condition (population), outcomes, modes of telerehabilitation program (intervention) delivery, and rehabilitation duration.

\section{Results}

\section{Study Identification}

Figure 1 shows an overview of the relevant study identification process using a four-step PRISMA (Preferred Reporting Items for Systematic Reviews and Meta-Analyses) [53] flow diagram. A total of 1198 studies were identified through the literature search: 119 in EMBASE, 807 in Scopus, 99 in Web of Knowledge, 165 in CINAHL, 97 in PubMed, 8 in PsycINFO, and 11 in the PEDro database. In total, 210 duplicated studies were found in the identified documents, and 909 articles were excluded by screening the titles and abstracts of the identified articles based on the defined inclusion criteria. The full text of 154 papers was reviewed by the authors in the eligibility stage, and 38 of the studies were included in this review. The eligible studies were reviewed, and studies using the same experimental setup and population were grouped together. Eventually, 24 group studies were chosen (Table 1). 
Figure 1. Flowchart of the results from the literature search. CINAHL: Cumulative Index to Nursing and Allied Health Literature; PEDro: Physiotherapy Evidence Database.

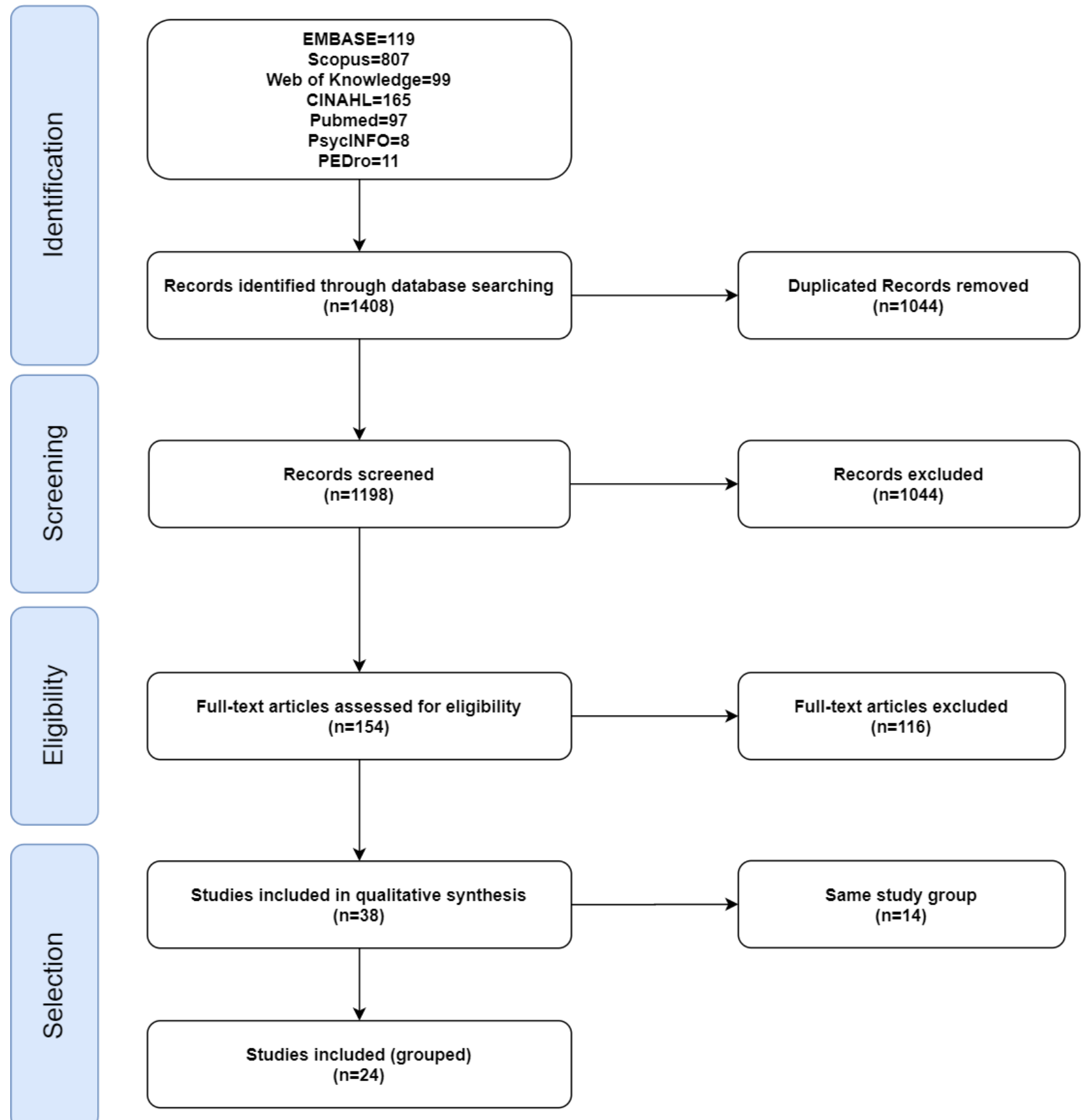


Table 1. Study characteristics.

\begin{tabular}{llllllll}
\hline $\begin{array}{l}\text { Group } \\
\text { year }\end{array}$ & $\begin{array}{l}\text { Author(s), } \\
\text { design }\end{array}$
\end{tabular}

P; Patients got a daily exercise program and were asked to perform exercises 3 times per day. They received a phone call every week.

RCT

TKA

101,101

PiS

$\mathrm{KnP}$ 2015 [60]
P. The patients received the standard rehabilitation program and were asked to perform exercises for 1 hour per day. They also received 3 phone calls.
P; Home training with a weekly phone call and logbook

$\mathrm{V}$; Video call at the secondary center with a group of patients and unsupervised home training.

V; Over 8 weeks, there were 16 video calls, which included the prescribing of an individualized training program.

V; Over 8 weeks, there were 16 video calls, which included the prescribing of an individualized training program.

V; Over 8 weeks, there were 16 video calls, which included the prescribing of an individualized training program.

$\mathrm{V}$; In-home training using 16 video calls over 8 weeks. Treatment, assessment, and recommendations were considered in the video sessions.

$\mathrm{V}$; In-home training using 16 video calls over 8 weeks. Treatment, assessment, and recommendations were considered in the video sessions.

$\mathrm{V}$; In-home training using 16 video calls over 8 weeks. Treatment, assessment, and recommendations were considered in the video sessions.

$\mathrm{V}$; In-home training using 16 video calls over 8 weeks. Treatment, assessment, and recommendations were considered in the video sessions.
The intervention group achieved noninferior outcomes (pain and function) compared with usual care physiotherapy.

A structured telephone follow-up may improve patient adherence as well as enhance patient mental health and range of motion.

The telerehabilitation was as effective as regular rehabilitation, and no significant difference was observed between the study groups.

Videoconferencing was accepted as a mode of health care service delivery among the users. Significant reductions were observed in pain level and stiffness, and there was an improvement in physical function and the Berg Balance Scale score.

A high level of participant satisfaction was achieved, and positive patient-therapist relationships were established.

The home telerehabilitation was as effective as conventional home visits in terms of reducing disability and improving function in the short term.

Patient and therapist satisfaction were high and comparable to that of conventional therapy.

The telerehabilitation was as effective as conventional face-to-face rehabilitation in terms of functional recovery and quality of life.

The telerehabilitation program was less expensive compared to conventional home visits when the distance between the health care center and patients was more than 30 $\mathrm{km}$.

Patient satisfaction was reported high for both control and intervention groups. No strong correlation was found between reported satisfaction and measurements.

The telerehabilitation program was reliable; however, the program required technical maintenance, support, and initial installation. 


\begin{tabular}{|c|c|c|c|c|c|c|c|}
\hline Group & $\begin{array}{l}\text { Author(s), } \\
\text { year }\end{array}$ & $\begin{array}{l}\text { Study } \\
\text { design }^{\text {a }}\end{array}$ & Population ${ }^{\mathrm{b}}$ & $\begin{array}{l}\text { Patients } \\
\text { (control, } \\
\text { target) }\end{array}$ & $\begin{array}{l}\text { Duration } \\
\text { (weeks) }\end{array}$ & Intervention type ${ }^{\mathrm{c}}$ and detail & Finding \\
\hline 8 & $\begin{array}{l}\text { Bini et al, } \\
2017[62]\end{array}$ & $\mathrm{RCT}$ & TKA & 15,13 & 12 & $\begin{array}{l}\text { V; Asynchronous video communica- } \\
\text { tion using a mobile app. }\end{array}$ & $\begin{array}{l}\text { No significant difference was ob- } \\
\text { served between study groups in } \\
\text { any of the outcomes. A high level } \\
\text { of patient acceptance and satisfac- } \\
\text { tion was achieved. Asynchronous } \\
\text { communication may overcome the } \\
\text { limitations of real-time telerehabil- } \\
\text { itation. }\end{array}$ \\
\hline
\end{tabular}

9

$\begin{array}{lllll}\text { Doiron- } & \text { RCT } & \text { HKA } & 12,22 & 12\end{array}$

Cadrin et al, 2018 [63]

V; Video telerehabilitation sessions were performed twice per week, and patients were asked to repeat the exercises unsupervised.

\section{0}

Eisermann et R
al, 2004 [64]

11

Piqueras et RCT

al, 2013 [65]
Ayoade and $\quad$ RCT
Baillie, 2014

[66]

$13^{\mathrm{e}}$

Correia et al, RCT 2018 [67] 2019 [68] 2019 [69]

et al, 2019

FiS

[70] 2019 [71] 2019 [72]

TKA

TKA

TKA

TKA $\stackrel{\mathrm{d}}{ }, 15$

2

$\mathrm{S}$; Training at home using a wearable sensor and customized Android application.

$\mathrm{S}$; Training at home using a leg sleeve equipped with two wearable sensors communicating with an iPhone. Daily activities were measured based on the internal pedometer of the phone.

S; Microsoft Kinect was used and therapist could actively modify the exercises. Real-time video communication was used to establish the communication.

$\mathrm{S}$; An interactive training program was presented, and Microsoft Kinect was used to track the exercises. The therapist could track patient performance and modify the training program. The system provided real-time video communication as well.
High level of patient satisfaction and adherence to the intervention program were achieved. No significant differences were observed between groups for all measurements. Telerehabilitation seems feasible and safe.

The provided solution was feasible and as effective as conventional therapy.

The proposed telerehabilitation program was at least as effective as conventional therapy. Significant improvement was observed in active extension range and quadriceps muscle strength.

The system was acceptable among the seniors. However; it did not improve their adherence.

Performance tests, range of motion, and patient-reported outcomes were significantly higher in the intervention group.

High levels of adherence to the program and satisfaction were reported. All the outcomes were significantly higher in the intervention group at 3 months and primary outcomes at 6 months.

High level of adherence to the intervention was reported, and overall positive user-experience achieved. Technical issues caused some negative experiences.

Patients found the telerehabilitation program engaging, motivating, and easy to use.

The effect of the telerehabilitation therapy was equivalent to the usual aftercare in terms of functional testing, quality of life, and pain.

The program was as effective as traditional treatment (function and disability) and as safe as traditional treatment (pain and rehospitalization). 


\begin{tabular}{|c|c|c|c|c|c|c|c|}
\hline Group & $\begin{array}{l}\text { Author(s), } \\
\text { year }\end{array}$ & $\begin{array}{l}\text { Study } \\
\text { design }^{\text {a }}\end{array}$ & Population $^{b}$ & $\begin{array}{l}\text { Patients } \\
\text { (control, } \\
\text { target) }\end{array}$ & $\begin{array}{l}\text { Duration } \\
\text { (weeks) }\end{array}$ & Intervention type ${ }^{c}$ and detail & Finding \\
\hline 18 & $\begin{array}{l}\text { Kuether et } \\
\text { al, } 2019 \text { [73] }\end{array}$ & PiS & HKA & ${ }^{\mathrm{d}}, 40$ & $\approx 8$ & $\begin{array}{l}\mathrm{S} ; \text { An interactive training program } \\
\text { was presented and Microsoft Kinect } \\
\text { was used to track the exercises. The } \\
\text { therapist could track patient perfor- } \\
\text { mance and modify the training pro- } \\
\text { gram. The system provided real-time } \\
\text { video communication as well. }\end{array}$ & $\begin{array}{l}\text { High satisfaction rate was ob- } \\
\text { served among the patients, and } \\
\text { comparable improvement in the } \\
\text { patient-reported outcomes were } \\
\text { achieved. }\end{array}$ \\
\hline 19 & $\begin{array}{l}\text { Chughtai et } \\
\text { al, } 2019 \text { [74] }\end{array}$ & FiS & KA & $-^{\mathrm{d}}, 157$ & $\approx 4$ & $\begin{array}{l}\mathrm{S} ; \text { An interactive training program } \\
\text { was presented and Microsoft Kinect } \\
\text { was used to track the exercises. The } \\
\text { therapist could track patient perfor- } \\
\text { mance and modify the training pro- } \\
\text { gram. The system provided real-time } \\
\text { video communication as well. }\end{array}$ & $\begin{array}{l}\text { The intervention was cost-effec- } \\
\text { tive, convenient, and improved } \\
\text { patient adherence and overall satis- } \\
\text { faction. }\end{array}$ \\
\hline 20 & $\begin{array}{l}\text { Bossen et al, } \\
2013 \text { [75] }\end{array}$ & PiS & HKO & $-^{\mathrm{d}}, 20$ & 9 & $\begin{array}{l}\text { E; Web-based exercise management } \\
\text { gradually increases the activity level } \\
\text { over } 9 \text { weeks without physiotherapist } \\
\text { involvement. }\end{array}$ & $\begin{array}{l}\text { The intervention was feasible and } \\
\text { accepted among the patients. Pa- } \\
\text { tient satisfaction was reported } \\
\text { high. }\end{array}$ \\
\hline 20 & $\begin{array}{l}\text { Bossen et al, } \\
2013 \text { [76] }\end{array}$ & Mix & $\mathrm{HKO}$ & $-^{\mathrm{d}}, 100$ & 9 & $\begin{array}{l}\text { E; Web-based exercise management } \\
\text { gradually increases the activity level } \\
\text { over } 9 \text { weeks without physiotherapist } \\
\text { involvement. }\end{array}$ & $\begin{array}{l}\text { Higher age, presence of comorbid- } \\
\text { ity, lack of self-discipline, and } \\
\text { physical activity baseline have a } \\
\text { negative impact on the interven- } \\
\text { tion adherence rate. }\end{array}$ \\
\hline $20^{\mathrm{e}}$ & $\begin{array}{l}\text { Bossen et al, } \\
2013 \text { [77] }\end{array}$ & RCT & HKO & 99,100 & 9 & $\begin{array}{l}\text { E; Web-based exercise management } \\
\text { gradually increases the activity level } \\
\text { over } 9 \text { weeks without physiotherapist } \\
\text { involvement. }\end{array}$ & $\begin{array}{l}\text { In the intervention group, physical } \\
\text { function status improved in the } \\
\text { short term; in the long term, higher } \\
\text { levels of subjective and objective } \\
\text { physical activity were observed. }\end{array}$ \\
\hline 21 & $\begin{array}{l}\text { Rini et al, } \\
2015 \text { [78] }\end{array}$ & $\mathrm{RCT}$ & HKO & 55,58 & $8-10$ & $\begin{array}{l}\text { E; Automatically generated training } \\
\text { program and management based on } \\
\text { feedback without therapist participa- } \\
\text { tion. }\end{array}$ & $\begin{array}{l}\text { The intervention group reported } \\
\text { significantly lower pain compared } \\
\text { with the control group and a very } \\
\text { high level of adherence to the inter- } \\
\text { vention program was observed. } \\
\text { The acceptability of the program } \\
\text { was demonstrated based on the } \\
\text { strong evidence. }\end{array}$ \\
\hline 22 & $\begin{array}{l}\text { Kim et al, } \\
2016 \text { [79] }\end{array}$ & RCT & $\mathrm{KnP}$ & 20,50 & 6 & $\begin{array}{l}\text { E; Training program generated and } \\
\text { updated automatically with therapist } \\
\text { involvement. }\end{array}$ & $\begin{array}{l}\text { No statistical difference was ob- } \\
\text { served between the control and in- } \\
\text { tervention groups. Only } 8 \% \text { of the } \\
\text { participants completed the pro- } \\
\text { gram. }\end{array}$ \\
\hline 23 & $\begin{array}{l}\text { Hinman et } \\
\text { al, } 2017 \text { [33] }\end{array}$ & Mix & $\mathrm{KnP} / \mathrm{KOA}$ & ${ }^{\mathrm{d}}, 12$ & 12 & $\begin{array}{l}\text { E/V; Home training ( } 3 \text { times per } \\
\text { week) and } 7 \text { video calls during the } \\
\text { treatment period. }\end{array}$ & $\begin{array}{l}\text { Patients were satisfied with the } \\
\text { provided solution due to the time } \\
\text { efficiency, flexibility of service, } \\
\text { and ease of access. } \\
\text { The solution also improved users' } \\
\text { confidence and sense of self-effica- } \\
\text { cy. }\end{array}$ \\
\hline $23^{\mathrm{e}}$ & $\begin{array}{l}\text { Bennell et al, } \\
2017 \text { [80] }\end{array}$ & RCT & $\mathrm{KnP}$ & 74,74 & 12 & $\begin{array}{l}\text { E/V; Home training ( } 3 \text { times per } \\
\text { week) and } 7 \text { video calls during the } \\
\text { treatment period. }\end{array}$ & $\begin{array}{l}\text { Short-term and long-term effective- } \\
\text { ness of the intervention was } \\
\text { achieved. A significant short-term } \\
\text { improvement was observed in the } \\
\text { primary outcomes. }\end{array}$ \\
\hline 23 & $\begin{array}{l}\text { Lawford et } \\
\text { al, } 2018 \text { [81] }\end{array}$ & $\mathrm{RCT}$ & $\mathrm{KnP}$ & 74,74 & 12 & $\begin{array}{l}\text { E/V; Home training ( } 3 \text { times per } \\
\text { week) and } 7 \text { video calls during the } \\
\text { treatment period. }\end{array}$ & $\begin{array}{l}\text { Employed participants with a } \\
\text { higher self-efficacy had better im- } \\
\text { provement in their health condition } \\
\text { compared to the rest of the study } \\
\text { group. }\end{array}$ \\
\hline
\end{tabular}




\begin{tabular}{|c|c|c|c|c|c|c|c|}
\hline Group & $\begin{array}{l}\text { Author(s), } \\
\text { year }\end{array}$ & $\begin{array}{l}\text { Study } \\
\text { design }^{\text {a }}\end{array}$ & Population ${ }^{b}$ & $\begin{array}{l}\text { Patients } \\
\text { (control, } \\
\text { target) }\end{array}$ & $\begin{array}{l}\text { Duration } \\
\text { (weeks) }\end{array}$ & Intervention type ${ }^{c}$ and detail & Finding \\
\hline 24 & $\begin{array}{l}\text { Bossen et al, } \\
2016 \text { [82] }\end{array}$ & Mix & $\mathrm{HKO}$ & $-^{\mathrm{d}}, 8$ & 9 & $\begin{array}{l}\text { E; Web-based exercise management } \\
\text { with gradual increases in the activity } \\
\text { level over } 12 \text { weeks; the therapist } \\
\text { could update the program, which in- } \\
\text { cluded } 5 \text { face-to-face visits. }\end{array}$ & $\begin{array}{l}\text { The proposed treatment seems to } \\
\text { be feasible, and a good level of } \\
\text { usability was reported. Lack of } \\
\text { possibility to monitor patients be- } \\
\text { tween sessions was considered a } \\
\text { limitation. }\end{array}$ \\
\hline 24 & $\begin{array}{l}\text { Vries et al, } \\
2017 \text { [83] }\end{array}$ & Mix & HKO & $-^{\mathrm{d}}, 90$ & 12 & $\begin{array}{l}\text { E; Web-based exercise management } \\
\text { with gradual increases in the activity } \\
\text { level over } 12 \text { weeks; the therapist } \\
\text { could update the program, which in- } \\
\text { cluded } 5 \text { face-to-face visits. }\end{array}$ & $\begin{array}{l}\text { Internet skills, self-discipline, us- } \\
\text { ability of the intervention, added } \\
\text { value, time required, flexibility, } \\
\text { and execution of the exercise plan } \\
\text { and participating in research iden- } \\
\text { tified as determinants of patients' } \\
\text { adherence. }\end{array}$ \\
\hline 24 & $\begin{array}{l}\text { Kloek et al, } \\
2018 \text { [84] }\end{array}$ & RCT & $\mathrm{HKO}$ & 99,109 & 12 & $\begin{array}{l}\text { E; Web-based exercise management } \\
\text { with gradual increases in the activity } \\
\text { level over } 12 \text { weeks; the therapist } \\
\text { could update the program, which in- } \\
\text { cluded } 5 \text { face-to-face visits. }\end{array}$ & $\begin{array}{l}\text { The intervention cost was signifi- } \\
\text { cantly lower in the intervention } \\
\text { group. However; the total societal } \\
\text { and healthcare costs were not sta- } \\
\text { tistically significant between } \\
\text { groups. }\end{array}$ \\
\hline 24 & $\begin{array}{l}\text { Kloek et al, } \\
2018 \text { [85] }\end{array}$ & Mix & $\mathrm{HKO}$ & $-^{\mathrm{f}},-^{\mathrm{f}}$ & 12 & $\begin{array}{l}\text { E; Web-based exercise management } \\
\text { with gradual increases in the activity } \\
\text { level over } 12 \text { weeks; the therapist } \\
\text { could update the program, which in- } \\
\text { cluded } 5 \text { face-to-face visits. }\end{array}$ & $\begin{array}{l}\text { Appropriateness, required time, } \\
\text { workload, added value, environ- } \\
\text { mental factors, professional auton- } \\
\text { omy, and financial consequences } \\
\text { were identified as determinants for } \\
\text { physiotherapists' usage of the } \\
\text { proposed intervention }\end{array}$ \\
\hline $24^{\mathrm{e}}$ & $\begin{array}{l}\text { Kloek et al, } \\
2018 \text { [86] }\end{array}$ & RCT & $\mathrm{HKO}$ & 99,109 & 12 & $\begin{array}{l}\text { E; Web-based exercise management } \\
\text { with gradual increases in the activity } \\
\text { level over } 12 \text { weeks; the therapist } \\
\text { could update the program, which in- } \\
\text { cluded } 5 \text { face-to-face visits. }\end{array}$ & $\begin{array}{l}\text { No statistical differences were } \\
\text { found between control and inter- } \\
\text { vention groups in physical func- } \\
\text { tioning and free-living physical } \\
\text { activity. }\end{array}$ \\
\hline
\end{tabular}

${ }^{\text {a}}$ The study designs are randomized controlled trial (RCT), mixed method study (Mix), quasi-experimental study (QeS), pilot study (PiS), feasibility study (FiS), and cross-sectional study (CrS).

${ }^{\mathrm{b}}$ The population groups are total hip/knee arthroplasty (HKA), knee osteoarthritis (KOA), total knee arthroplasty (TKA), knee pain (KnP), and hip/knee osteoarthritis (HKO).

${ }^{\mathrm{c}}$ For the intervention type, the designations P, V, S, and E stand for phone-based, video-based, sensor-based, and expert system-based telerehabilitation, respectively.

${ }^{\mathrm{d}}$ Not available.

${ }^{\mathrm{e}}$ These studies are considered the reference study of their group.

${ }^{\mathrm{f}}$ There were 123 physiotherapists that participated in the study.

\section{Technologies and Mode of Rehabilitation Service Delivery}

We identified four modes of telerehabilitation programs: phone-based, video-based, sensor-based, and expert system-based; we focused on the given training solution.

\section{Phone-Based Telerehabilitation}

Azma et al [57] and Han et al [55] used weekly phone communication initiated by a health care professional who would instruct patients and track their progress over the rehabilitation period. Kramer et al [54] and Chen et al [56] performed less frequent phone calls during the rehabilitation period. In the studies, training instructions were provided using a guidebook of the exercises. Information about adherence to the exercise programs was collected by filling out a logbook of activities [57] or during the phone calls [55].

\section{Video-Based Telerehabilitation}

In previous studies, real-time video streaming communication was frequently used to deliver rehabilitation services to patients. Wong et al [58] established a weekly supervised training session with a group of patients using video conference communication at a secondary center. Patients were asked to perform the prescribed exercises 3 times per week for 12 weeks using a booklet of exercise instructions; patient activity/adherence was reported using a logbook. Tousignant et al [30] provided a home telerehabilitation service by setting up a video conferencing system in the patient's home, and rehabilitation sessions were carried out twice per week for 8 weeks. Moffet et al [60] developed the telerehabilitation solution by employing a hardware/software video communication platform (TelAge), which was the treatment program for the target group. In the TelAge system, custom computer software (TeRa) was developed to control the streaming video with a user-friendly 
graphical interface [61]. Doiron-Cadrin et al [63] employed a medical teleconsultation application (REACTS Lite, Innovative Imaging Technologies) to establish real-time video communication.

Bini et al [62] introduced asynchronous video communication by employing smart devices (iPod Touch, Apple Inc) and media file-sharing applications (CaptureProof). The system established a two-way asynchronous communication between the physiotherapist and patient. It also enabled the physiotherapist to instruct the patient using prerecorded exercise introductions and provide supplementary media.

\section{Sensor-Based Telerehabilitation}

Eisermann et al [64] provided a telerehabilitation program using custom computer software and several sensors to track the patient's performance. Patients were asked to perform individualized exercises based on the training program prescribed by the therapist; the program could be modified based on the patient's feedback. Accelerometers, webcams, chest sensors, and wristbands were employed in the study to monitor training performance and generate relevant reports and online feedback.

Ayoade et al [66] and Piqueras et al [65] developed a telerehabilitation program by using two wireless sensors equipped with 9 degrees of freedom (9DOF) inertial measurement units to track the knee angle. Participants were asked to wear the sensors on their operated leg (shin and thigh) using elastic bands while performing the recommended exercises. Argent et al [69] used a classic Bluetooth 9DOF sensor (Shimmer3, Shimmer Sensing) fixed on the patient's shin, and Correia et al [67] increased the number of Bluetooth Low Energy 9DOF sensors to three; these were placed on the chest, thigh, and shin. Ramkumar et al [70,87] employed Focus Motion (Focus Ventures) sleeves to track the operated knee's range of motion. The sleeve was designed for the lower limb and equipped with two classic Bluetooth 9DOF sensors. In addition, the user's cellphone was used to track daily activities based on the internal pedometer.

Eichler et al [71,88] used Microsoft Kinect (Version 2, Microsoft Corp) in the training program to track the patient's performance. The VERA (Reflexion Health) system also used Microsoft Kinect to track the exercises and it has been used in several clinical studies [72-74]. The Microsoft Kinect software development kit (Version 2.0) [89] can provide an estimation of 25 joins (including the knee) in space. Therefore, the telerehabilitation program could produce an avatar of the user performing the exercises.

All the introduced telerehabilitation programs were able to track the number of performed exercises and to provide real-time visual feedback on user performance.

\section{Expert System-Based Telerehabilitation}

Bossen et al [77] provided a web-based training program (Join2Move). The training program was automatically generated based on reported baseline measurements. The intensity of the exercises was increased over time, based on the behavioral graded activity concept [90]. The expert system collected weekly patient adherence reports and provided autogenerated messages and reports without any intervention by the physiotherapist. The telerehabilitation program was improved and developed using a participatory design method [82,91]. In the improved program (E-exercise), online information and 5 face-to-face visits were included in the internet-based intervention [86]. Moreover, in E-exercise, it was observed that the therapist could deviate from the suggested training program.

Kim et al [79] used a decision-making system that introduced an adaptive training program based on the patient's adherence, pain level, and difficulty reports. However, the physiotherapists were not involved in adjusting the training program; they were able to monitor the patient's reports and respond to the patient's questions via a text messaging service embedded in the program.

Rini et al [78] employed an expert system to provide internet-based pain coping skills training (PainCoach). An individualized training program was automatically generated based on the patient's baseline without physiotherapist participation. In addition, the program enabled the patients to access the appropriate instructions and a history of their performance; they could also ask other patients about their experiences and share experiences. Bennell et al [80] extended the PainCoach program by including 7 videoconference sessions with a physiotherapist over 12 weeks.

\section{Intervention and Services}

In total, five different services were identified in the included papers. Table 2 shows the introduced services as part of the telerehabilitation program. The details regarding services were provided as follows.

\section{Information}

The information service provided relevant educational material for the target group and was accessible on a 24/7 basis without any interruption. The information provided could cover a wide variety of instructions and answer questions; in addition, it could introduce critical challenges that the patient might encounter. Only four of the studies introduced education materials via an online service as a part of the rehabilitation program.

\section{Communication}

The two-way communication between the patient and health care professionals can be used for consultation, recommendation, and interview purposes. The majority of the studies provided this service (19 studies). Real-time communication (using the phone or a video call) was used more than asynchronized communication (asynchronous SMS text messaging or video messaging). In the phone-based and video-based solutions, the communication platform was also used to deliver the training services. It should be mentioned that two of the studies $[67,86]$ chose to include regular in-person visits. Eichler et al [71] used both real-time videoconferencing and asynchronous messaging approaches in the program.

\section{Training}

The training service includes exercise instructions, daily/weekly rehabilitation plans (number of repetitions and sets for each exercise) and relevant interactive materials for each exercise. All the studies provided training services using an interactive 
training program with visual feedback, video rehabilitation sessions, or a printed booklet of instructions.

\section{Intervention}

Intervention in a telerehabilitation program can be carried out based on the patient's reports and is done individually by either a physiotherapist or a decision-making algorithm (as part of an expert system). Making adjustments and modifications to the training program (ie, repetitions, intensity, number of exercises) and providing relevant feedback are considered as interventions in the treatment.

\section{Monitoring and Tracking}

Monitoring and tracking services enable physiotherapists or an expert system to perform a predefined assessment or diagnosis remotely. In addition, this service may provide a history of the patient's performance. The data can be recorded manually by a physiotherapist, self-reported by the patient (such as adherence or pain level), or collected automatically using motion tracking sensors. 
Table 2. Details of the services provided in the included telerehabilitation programs.

\begin{tabular}{|c|c|c|c|c|c|c|}
\hline Group & Main study & Information & Communication & Training & Intervention & Tracking \\
\hline 1 & $\begin{array}{l}\text { Kramer et al, } \\
2003 \text { [54] }\end{array}$ & Booklet & Phone call & $\begin{array}{l}\text { Instruction booklet of } \\
\text { the exercises }\end{array}$ & Phone call & $\mathrm{N} / \mathrm{A}^{\mathrm{a}}$ \\
\hline 2 & $\begin{array}{l}\text { Han et al, } 2015 \\
{[55]}\end{array}$ & N/A & Phone call & $\begin{array}{l}\text { A hard copy of the in- } \\
\text { structions }\end{array}$ & Phone call & $\begin{array}{l}\text { Adherence (by phone } \\
\text { call) }\end{array}$ \\
\hline 3 & $\begin{array}{l}\text { Chen et al, } 2016 \\
\text { [56] }\end{array}$ & N/A & Phone call & $\begin{array}{l}\text { A hard copy of the in- } \\
\text { structions }\end{array}$ & Phone call & Unclear \\
\hline 4 & $\begin{array}{l}\text { Azma et al, } \\
2017 \text { [57] }\end{array}$ & N/A & Phone call & $\begin{array}{l}\text { Instruction booklet of } \\
\text { the exercises }\end{array}$ & Phone call & Adherence logbook \\
\hline 5 & $\begin{array}{l}\text { Wong et al, } \\
2005[58]\end{array}$ & N/A & $\begin{array}{l}\text { Real-time video com- } \\
\text { munication }\end{array}$ & $\begin{array}{l}\text { Instruction booklet of } \\
\text { the exercises }\end{array}$ & Unclear & $\begin{array}{l}\text { Real-time video commu- } \\
\text { nication }\end{array}$ \\
\hline 6 & $\begin{array}{l}\text { Tousignant et } \\
\text { al, } 2011[30]\end{array}$ & N/A & $\begin{array}{l}\text { Real-time video com- } \\
\text { munication }\end{array}$ & $\begin{array}{l}\text { Real-time video com- } \\
\text { munication }\end{array}$ & $\begin{array}{l}\text { A therapist can modify } \\
\text { the training program }\end{array}$ & $\begin{array}{l}\text { Real-time video commu- } \\
\text { nication }\end{array}$ \\
\hline 7 & $\begin{array}{l}\text { Moffet et al, } \\
2015 \text { [60] }\end{array}$ & N/A & $\begin{array}{l}\text { Real-time video com- } \\
\text { munication }\end{array}$ & $\begin{array}{l}\text { Real-time video com- } \\
\text { munication }\end{array}$ & $\begin{array}{l}\text { A therapist can modify } \\
\text { the training program }\end{array}$ & $\begin{array}{l}\text { Real-time video commu- } \\
\text { nication }\end{array}$ \\
\hline 8 & $\begin{array}{l}\text { Bini et al, } 2017 \\
\text { [62] }\end{array}$ & N/A & $\begin{array}{l}\text { Asynchronous video } \\
\text { communication }\end{array}$ & $\begin{array}{l}\text { Video instruction of } \\
\text { the training program }\end{array}$ & $\begin{array}{l}\text { A therapist can modify } \\
\text { the training program }\end{array}$ & Video reports \\
\hline 9 & $\begin{array}{l}\text { Doiron-Cadrin } \\
\text { et al, } 2018[63]\end{array}$ & N/A & $\begin{array}{l}\text { Real-time video com- } \\
\text { munication }\end{array}$ & $\begin{array}{l}\text { Real-time video com- } \\
\text { munication }\end{array}$ & $\begin{array}{l}\text { Real-time video commu- } \\
\text { nication }\end{array}$ & Adherence using logbook \\
\hline 10 & $\begin{array}{l}\text { Eisermann et al, } \\
2004 \text { [64] }\end{array}$ & N/A & $\begin{array}{l}\text { Asynchronous text } \\
\text { messaging }\end{array}$ & $\begin{array}{l}\text { An interactive training } \\
\text { program with real- } \\
\text { time feedback using } \\
\text { motion sensors }\end{array}$ & $\begin{array}{l}\text { A therapist can modify } \\
\text { the training program }\end{array}$ & $\begin{array}{l}\text { Patient performance col- } \\
\text { lected by sensors and re- } \\
\text { ported }\end{array}$ \\
\hline 11 & $\begin{array}{l}\text { Piqueras et al, } \\
2013 \text { [65] }\end{array}$ & N/A & Unclear & $\begin{array}{l}\text { An interactive training } \\
\text { program with real- } \\
\text { time feedback using } \\
\text { motion sensors }\end{array}$ & $\begin{array}{l}\text { A therapist can modify } \\
\text { the training program }\end{array}$ & $\begin{array}{l}\text { Patient performance col- } \\
\text { lected by sensors and re- } \\
\text { ported }\end{array}$ \\
\hline 12 & $\begin{array}{l}\text { Ayoade and } \\
\text { Baillie, } 2014 \\
{[66]}\end{array}$ & N/A & $\begin{array}{l}\text { Real-time video com- } \\
\text { munication }\end{array}$ & $\begin{array}{l}\text { An interactive training } \\
\text { program with real- } \\
\text { time feedback using } \\
\text { motion sensors }\end{array}$ & $\begin{array}{l}\text { Real-time video commu- } \\
\text { nication }\end{array}$ & Unclear \\
\hline 13 & $\begin{array}{l}\text { Correia et al, } \\
2018 \text { [67] }\end{array}$ & N/A & $\begin{array}{l}\text { Face-to-face, phone } \\
\text { call }\end{array}$ & $\begin{array}{l}\text { Visual real-time feed- } \\
\text { back and audio instruc- } \\
\text { tions using motion } \\
\text { sensors }\end{array}$ & $\begin{array}{l}\text { A therapist can modify } \\
\text { the training program }\end{array}$ & $\begin{array}{l}\text { System generated perfor- } \\
\text { mance }\end{array}$ \\
\hline 14 & $\begin{array}{l}\text { Argent et al, } \\
2019 \text { [69] }\end{array}$ & $\begin{array}{l}\text { Provided by the } \\
\text { application }\end{array}$ & Unclear & $\begin{array}{l}\text { An interactive training } \\
\text { program with real- } \\
\text { time feedback using } \\
\text { motion sensors }\end{array}$ & Unclear & $\begin{array}{l}\text { Adherence (performance) } \\
\text { collected by the system } \\
\text { and patient reports (pain, } \\
\text { difficulty) }\end{array}$ \\
\hline 15 & $\begin{array}{l}\text { Ramkumar et } \\
\text { al, } 2019 \text { [70] }\end{array}$ & Unclear & Unclear & $\begin{array}{l}\text { An interactive training } \\
\text { program with real- } \\
\text { time feedback using } \\
\text { motion sensors }\end{array}$ & Unclear & $\begin{array}{l}\text { Adherence and daily } \\
\text { steps were collected auto- } \\
\text { matically, and patient-re- } \\
\text { ported outcome data } \\
\text { were reported every week } \\
\text { electronically. }\end{array}$ \\
\hline 16 & $\begin{array}{l}\text { Eichler et al, } \\
2019 \text { [71] }\end{array}$ & N/A & $\begin{array}{l}\text { Asynchronous SMS } \\
\text { text and voice messag- } \\
\text { ing as well as real- } \\
\text { time video communi- } \\
\text { cation }\end{array}$ & $\begin{array}{l}\text { An interactive training } \\
\text { program with real- } \\
\text { time feedback using } \\
\text { Microsoft Kinect }\end{array}$ & $\begin{array}{l}\text { A therapist can modify } \\
\text { the training program. }\end{array}$ & $\begin{array}{l}\text { Patient adherence and } \\
\text { performance collected } \\
\text { and reported }\end{array}$ \\
\hline 17 & $\begin{array}{l}\text { Bettger et al, } \\
2019 \text { [72] }\end{array}$ & N/A & $\begin{array}{l}\text { Real-time video com- } \\
\text { munication }\end{array}$ & $\begin{array}{l}\text { An interactive training } \\
\text { program with real- } \\
\text { time feedback using } \\
\text { Microsoft Kinect }\end{array}$ & $\begin{array}{l}\text { A therapist can modify } \\
\text { the training program. }\end{array}$ & $\begin{array}{l}\text { Patient adherence and } \\
\text { performance collected } \\
\text { and reported }\end{array}$ \\
\hline
\end{tabular}




\begin{tabular}{|c|c|c|c|c|c|c|}
\hline Group & Main study & Information & Communication & Training & Intervention & Tracking \\
\hline 18 & $\begin{array}{l}\text { Kuether et al, } \\
2019 \text { [73] }\end{array}$ & N/A & $\begin{array}{l}\text { Real-time video com- } \\
\text { munication }\end{array}$ & $\begin{array}{l}\text { An interactive training } \\
\text { program with real- } \\
\text { time feedback using } \\
\text { Microsoft Kinect }\end{array}$ & $\begin{array}{l}\text { A therapist can modify } \\
\text { the training program. }\end{array}$ & $\begin{array}{l}\text { Adherence to the pro- } \\
\text { gram reported automati- } \\
\text { cally. }\end{array}$ \\
\hline 19 & $\begin{array}{l}\text { Chughtai et al, } \\
2019 \text { [74] }\end{array}$ & N/A & $\begin{array}{l}\text { Real-time video com- } \\
\text { munication }\end{array}$ & $\begin{array}{l}\text { An interactive training } \\
\text { program with real- } \\
\text { time feedback using } \\
\text { Microsoft Kinect }\end{array}$ & $\begin{array}{l}\text { A therapist can modify } \\
\text { the training program. }\end{array}$ & $\begin{array}{l}\text { Adherence to the pro- } \\
\text { gram reported automati- } \\
\text { cally. }\end{array}$ \\
\hline 20 & $\begin{array}{l}\text { Bossen et al, } \\
2013 \text { [77] }\end{array}$ & $\begin{array}{l}\text { Online educa- } \\
\text { tion materials }\end{array}$ & N/A & $\begin{array}{l}\text { Interactive training } \\
\text { program }\end{array}$ & $\begin{array}{l}\text { The expert system } \\
\text { modifies the training } \\
\text { program }\end{array}$ & Adherence report \\
\hline 21 & $\begin{array}{l}\text { Rini et al, } 2015 \\
{[78]}\end{array}$ & $\begin{array}{l}\text { Online educa- } \\
\text { tion materials }\end{array}$ & $\mathrm{N} / \mathrm{A}$ & $\begin{array}{l}\text { Interactive training } \\
\text { program }\end{array}$ & $\begin{array}{l}\text { The expert system } \\
\text { modifies the training } \\
\text { program }\end{array}$ & Patient reports \\
\hline 22 & $\begin{array}{l}\text { Kim et al, } 2016 \\
\text { [79] }\end{array}$ & Unclear & $\begin{array}{l}\text { Asynchronous text } \\
\text { messaging }\end{array}$ & $\begin{array}{l}\text { Interactive training } \\
\text { program }\end{array}$ & $\begin{array}{l}\text { The expert system } \\
\text { modifies the training } \\
\text { program }\end{array}$ & Patient reports \\
\hline 23 & $\begin{array}{l}\text { Bennell et al, } \\
2017 \text { [80] }\end{array}$ & $\begin{array}{l}\text { Online educa- } \\
\text { tion materials }\end{array}$ & $\begin{array}{l}\text { Real-time video com- } \\
\text { munication }\end{array}$ & $\begin{array}{l}\text { Interactive training } \\
\text { program }\end{array}$ & $\begin{array}{l}\text { The expert system } \\
\text { modifies the training } \\
\text { program }\end{array}$ & Unclear \\
\hline 24 & $\begin{array}{l}\text { Kloek et al, } \\
2018[86]\end{array}$ & $\begin{array}{l}\text { Online educa- } \\
\text { tion materials }\end{array}$ & Face-to-face & $\begin{array}{l}\text { Interactive training } \\
\text { program }\end{array}$ & $\begin{array}{l}\text { The expert system and } \\
\text { therapist modify the } \\
\text { training program }\end{array}$ & Adherence report \\
\hline Overall & N/A & 6 & 19 & 24 & 21 & 20 \\
\hline
\end{tabular}

${ }^{\mathrm{a}} \mathrm{N} / \mathrm{A}$ : not applicable.

\section{Discussion}

This focused review had two purposes: to investigate the technologies used in telerehabilitation programs for patients with KOA and to identify the services that were introduced for the target group. The review identified 24 group studies. The majority of studies $(87.5 \%)$ were conducted in the second decade of the investigation period (2010-2020) and half of the studies published in the last 4 years. Four different modes of service delivery and five groups of services were identified. The findings showed that video-based communication was the most well-established mode of service delivery, and the studies primarily emphasized establishing training and intervention services rather than providing online education materials.

It is believed that limited services can be provided using a phone-based telerehabilitation program such as phone consultations, recommendations, and interviews [57,92,93], while real-time video communication can be seen as an alternative implementation of an in-person physiotherapy session. Real-time video can be employed not only for consultation purposes but also for training, intervention, and assessment services $[30,94,95]$. Video conferencing enables the physiotherapist to provide individualized instructions, feedback, and training programs for each patient in real time [59]. Cottrell et al [15] also concluded that real-time video telerehabilitation might be as effective as conventional therapy. Furthermore, the clinical assessment can be carried out by a physiotherapist via the visual observation of a patient's performance while performing a clinical test [59]. Capturing high-quality still images to assess the range of motion of a patient's knee is also recommended $[96,97]$. In addition, it has been shown that video conferencing can be carried out using a low-bandwidth internet connection [94,98].

Bini et al [62] remarked that real-time video communication might involve several limitations when compared to asynchronous video communication, such as time restrictions and limited or no access to the previous records. The video conference session is usually conducted according to predefined schedules (for example, twice per week in $[30,60]$ ), and patients were asked to repeat the exercises without any supervision [63]. Consequently, the patient cannot initiate on-demand communication. Moreover, storing the real-time video stream for later use requires more complicated infrastructure; therefore, neither the physiotherapist nor patients would have access to the previous sessions to track treatment progress. Russell et al [99] recommended a store and forward method to provide video instructions with higher quality. Perez-Manchon et al [100] stated that asynchronous telemedicine could be an efficient method for providing health care services at a distance. However, this method still requires the active engagement of the therapists to review the recorded video session.

Sensor-based telerehabilitation programs are a more independent service than video communication as they use one or more sensors to record the patient's physical activity and collect movement information using software running on a computer device (PC, smartphone, tablet). Ayoade and Baillie [66] showed that a sensor-based telerehabilitation program can offer increased time flexibility and independence for patients by using semi supervised training sessions. Interactive telerehabilitation can be provided by presenting real-time graphical feedback of the 
patient's performance using the software. In addition, interactive telerehabilitation enables users to review their performance over time. Moreover, several services can also be provided by software such as asynchronous or synchronous communication, educational materials, and patient reports. The program can be divided into wearable sensor-based and Microsoft Kinect-based programs. Earlier studies remarked that wearable sensors can provide accurate and precise details of movement [101-103]. However, several limitations were observed in the studies. Ayoade and Baillie [66] evaluated the system on only five patients, and Piqueras et al [65] reported that patients used the program for five days. Argent et al [69] reported that patients had a negative experience due to inconsistencies in the automatic measuring system. Ramkumar et al [70] remarked that the users did not appreciate the frequent charging of sensors. In addition, Naeemabadi et al [104] showed that Bluetooth Low Energy-based motion sensors might have a less accurate estimation of the sensor orientation due to a low sampling rate. Moreover, the sampling rate will also decline when the number of sensors is increased. Therefore, further investigation might be required to assess the real-time responsiveness of telerehabilitation programs like those introduced by Correia et al $[67,68]$. In general, wearable sensors can only represent the orientation of the limb to which they are attached. Therefore, the depicted avatar cannot represent the movement of the whole body. However, Microsoft Kinect-based solutions can track the whole body without the need to wear sensors. In addition, no calibration process is required, and users can immediately start the exercises. The portability of these solutions are debatable due to the computational requirement for Kinect. Eichler et al [71] used a small form factor PC attached to the user's TV; for the VERA solution, the PC, display, and Kinect sensor were placed in a case. Conversely, cellphones and tablets were used in the wearable sensor-based solutions. It was also shown that Microsoft Kinect might impose practical limitations on particular exercises [105]. Microsoft Kinect requires a large space to track the body and Eichler et al [71] consider this in the inclusion criteria. Hence, using Microsoft Kinect to track the exercises might be controversial. It is believed that we still lack a robust solution for the sensor-based telerehabilitation program. Hence, further studies are needed to provide a better understanding of these challenges.

The recent investigations showed that the expert system could partly or entirely interact with the patient and take the therapist's responsibilities. In only 2 out of the 5 identified studies, the expert system was entirely responsible for managing and supervising the treatment procedure, and the patient-to-therapist connection was disrupted $[77,78]$. Later on, both studies saw improvements, with physiotherapists being more involved in the treatment process via face-to-face visits [86] and video conference communication [80]. Kim et al [79] also used an asynchronous communication with a physiotherapist in the expert system that they introduced. We conclude that the expert system can be effectively used as an assistant system that allows the physiotherapist to have responsibility and maintain physiotherapist-patient telecommunication.

Russell [32] also recognized virtual reality-based telerehabilitation programs as a mode of telerehabilitation. However, we were not able to identify any studies that employed this mode based on the taxonomy of virtual reality displays [106].

In summary, video conference-based programs can be considered the well-established alternative solution to the conventional rehabilitation program for the target group; however, there remain several limitations, such as flexibility and resource management. The recent studies justified the effectiveness of this approach. Although sensor-based solutions might offer higher flexibility and better resource management. The investigations indicated, more studies are being conducted utilizing the sensor technology as a telerehabilitation in the last two years thanks to the existing demand for a more flexible and portable telerehabilitation with better human resource management.

\section{Acknowledgments}

This study was supported by the Aage and Johanne Louis-Hansen Foundation, Aalborg University, as well as the Orthopedic Surgery Research Unit, Science and Innovation Center, Aalborg University Hospital, Aalborg, Denmark.

\section{Conflicts of Interest}

None declared.

\section{References}

1. Guccione AA, Felson DT, Anderson JJ, Anthony JM, Zhang Y, Wilson PW, et al. The effects of specific medical conditions on the functional limitations of elders in the Framingham Study. Am J Public Health 1994 Mar;84(3):351-358. [doi: 10.2105/ajph.84.3.351] [Medline: $\underline{8129049]}$

2. Vos T, Flaxman AD, Naghavi M, Lozano R, Michaud C, Ezzati M, et al. Years lived with disability (YLDs) for 1160 sequelae of 289 diseases and injuries 1990-2010: a systematic analysis for the Global Burden of Disease Study 2010. In: The Lancet. Amsterdam, Netherlands: The Lancet; Dec 15, 2012:2163-2196.

3. Woolf AD. Global burden of osteoarthritis and musculoskeletal diseases. BMC Musculoskelet Disord 2015 Dec 1;16(S1). [doi: $10.1186 / 1471-2474-16-\mathrm{s} 1-\mathrm{s} 3$ ]

4. Smith E, Hoy DG, Cross M, Vos T, Naghavi M, Buchbinder R, et al. The global burden of other musculoskeletal disorders: estimates from the Global Burden of Disease 2010 study. Ann Rheum Dis 2014 Aug 03;73(8):1462-1469. [doi: 10.1136/annrheumdis-2013-204680] [Medline: 24590181] 
5. Zhang Y, Jordan JM. Epidemiology of osteoarthritis. Clin Geriatr Med 2010 Aug;26(3):355-369 [FREE Full text] [doi: 10.1016/j.cger.2010.03.001] [Medline: 20699159]

6. Nguyen U, Zhang Y, Zhu Y, Niu J, Zhang B, Felson DT. Increasing prevalence of knee pain and symptomatic knee osteoarthritis: survey and cohort data. Ann Intern Med 2011 Dec 06;155(11):725-732 [FREE Full text] [doi: 10.7326/0003-4819-155-11-201112060-00004] [Medline: 22147711]

7. Artz N, Elvers KT, Lowe CM, Sackley C, Jepson P, Beswick AD. Effectiveness of physiotherapy exercise following total knee replacement: systematic review and meta-analysis. BMC Musculoskelet Disord 2015 Feb 07;16(1):15 [FREE Full text] [doi: 10.1186/s12891-015-0469-6] [Medline: 25886975]

8. da Costa BR, Vieira ER, Gadotti IC, Colosi C, Rylak J, Wylie T, et al. How Do Physical Therapists Treat People with Knee Osteoarthritis, and What Drives Their Clinical Decisions? A Population-Based Cross-Sectional Survey. Physiother Can 2017 Feb;69(1):30-37 [FREE Full text] [doi: 10.3138/ptc.2015-83] [Medline: 28154442]

9. Lai JC, Woo J, Hui E, Chan W. Telerehabilitation - a new model for community-based stroke rehabilitation. J Telemed Telecare 2004 Jun 24;10(4):199-205. [doi: 10.1258/1357633041424340] [Medline: 15273029]

10. Inskip JA, Lauscher HN, Li LC, Dumont GA, Garde A, Ho K, et al. Patient and health care professional perspectives on using telehealth to deliver pulmonary rehabilitation. Chron Respir Dis 2018 Feb 18;15(1):71-80 [FREE Full text] [doi: 10.1177/1479972317709643] [Medline: 28569116]

11. Pinnock H, Hanley J, McCloughan L, Todd A, Krishan A, Lewis S, et al. Effectiveness of telemonitoring integrated into existing clinical services on hospital admission for exacerbation of chronic obstructive pulmonary disease: researcher blind, multicentre, randomised controlled trial. BMJ 2013 Oct 17;347(oct17 3):f6070-f6070 [FREE Full text] [doi: 10.1136/bmj.f6070] [Medline: 24136634]

12. Zanaboni P, Dinesen B, Hjalmarsen A, Hoaas H, Holland AE, Oliveira CC, et al. Long-term integrated telerehabilitation of COPD Patients: a multicentre randomised controlled trial (iTrain). BMC Pulm Med 2016 Aug 22;16(1):126 [FREE Full text] [doi: 10.1186/s12890-016-0288-z] [Medline: 27549782]

13. Piette E, Nougairède M, Vuong V, Crickx B, Tran V. Impact of a store-and-forward teledermatology intervention versus usual care on delay before beginning treatment: A pragmatic cluster-randomized trial in ambulatory care. J Telemed Telecare 2016 Aug 05;23(8):725-732. [doi: $10.1177 / 1357633 \times 16663328$ ]

14. Estai M, Kanagasingam Y, Xiao D, Vignarajan J, Huang B, Kruger E, et al. A proof-of-concept evaluation of a cloud-based store-and-forward telemedicine app for screening for oral diseases. J Telemed Telecare 2016 Sep 08;22(6):319-325. [doi: 10.1177/1357633X15604554] [Medline: 26377126]

15. Cottrell MA, Galea OA, O'Leary SP, Hill AJ, Russell TG. Real-time telerehabilitation for the treatment of musculoskeletal conditions is effective and comparable to standard practice: a systematic review and meta-analysis. Clin Rehabil 2017 May 02;31(5):625-638. [doi: 10.1177/0269215516645148] [Medline: 27141087]

16. Vaish A, Ahmed S, Shetty A. Remote physiotherapy monitoring using the novel D+R Therapy iPhone application. J Clin Orthop Trauma 2017 Jan;8(1):21-24 [FREE Full text] [doi: 10.1016/j.jcot.2016.08.008] [Medline: 28360491]

17. Deldar K, Bahaadinbeigy K, Tara A. Teleconsultation and Clinical Decision Making: a Systematic Review. Acta Inform Med 2016 Jul 16;24(4):286-292 [FREE Full text] [doi: 10.5455/aim.2016.24.286-292] [Medline: 27708494]

18. Finkelstein SM, Speedie SM, Demiris G, Veen M, Lundgren JM, Potthoff S. Telehomecare: quality, perception, satisfaction. Telemed J E Health 2004 Jun;10(2):122-128. [doi: 10.1089/tmj.2004.10.122] [Medline: 15319041]

19. Demiris G, Speedie SM, Finkelstein S. Change of patients' perceptions of TeleHomeCare. Telemed J E Health 2001 Sep;7(3):241-248. [doi: 10.1089/153056201316970948] [Medline: 11564360]

20. Russell TG. Telerehabilitation: a coming of age. Australian Journal of Physiotherapy 2009;55(1):5-6. [doi: 10.1016/s0004-9514(09)70054-6]

21. Cary MP, Spencer M, Carroll A, Hand DH, Amis K, Karan E, et al. Benefits and Challenges of Delivering Tele-rehabilitation Services to Rural Veterans. Home Healthcare Now 2016;34(8):440-446. [doi: 10.1097/nhh.0000000000000441]

22. Wiborg A, Widder B. Teleneurology to Improve Stroke Care in Rural Areas. Stroke 2003 Dec;34(12):2951-2956. [doi: 10.1161/01.str.0000099125.30731.97]

23. Tousignant M, Moffet H, Nadeau S, Mérette C, Boissy P, Corriveau H, et al. Cost analysis of in-home telerehabilitation for post-knee arthroplasty. J Med Internet Res 2015 Mar 31;17(3):e83 [FREE Full text] [doi: 10.2196/jmir.3844] [Medline: 25840501]

24. Kairy D, Lehoux P, Vincent C, Visintin M. A systematic review of clinical outcomes, clinical process, healthcare utilization and costs associated with telerehabilitation. Disabil Rehabil 2009 Jul 07;31(6):427-447. [doi: 10.1080/09638280802062553] [Medline: 18720118]

25. Fusco F, Turchetti G. Telerehabilitation after total knee replacement in Italy: cost-effectiveness and cost-utility analysis of a mixed telerehabilitation-standard rehabilitation programme compared with usual care. BMJ Open 2016 May 17;6(5):e009964 [FREE Full text] [doi: 10.1136/bmjopen-2015-009964] [Medline: 27188803]

26. Mani S, Sharma S, Omar B, Paungmali A, Joseph L. Validity and reliability of Internet-based physiotherapy assessment for musculoskeletal disorders: a systematic review. J Telemed Telecare 2016 Mar 31;23(3):379-391. [doi:

$10.1177 / 1357633 \times 16642369]$ 
27. Odole AC, Ojo OD. Is telephysiotherapy an option for improved quality of life in patients with osteoarthritis of the knee? Int J Telemed Appl 2014;2014:903816-903819 [FREE Full text] [doi: 10.1155/2014/903816] [Medline: 24778645]

28. Jiang S, Xiang J, Gao X, Guo K, Liu B. The comparison of telerehabilitation and face-to-face rehabilitation after total knee arthroplasty: A systematic review and meta-analysis. J Telemed Telecare 2016 Dec 27;24(4):257-262. [doi: $10.1177 / 1357633 \times 16686748]$

29. Sharareh B, Schwarzkopf R. Effectiveness of telemedical applications in postoperative follow-up after total joint arthroplasty. J Arthroplasty 2014 May;29(5):918-922.e1. [doi: 10.1016/j.arth.2013.09.019] [Medline: 24342278]

30. Tousignant M, Moffet H, Boissy P, Corriveau H, Cabana F, Marquis F. A randomized controlled trial of home telerehabilitation for post-knee arthroplasty. J Telemed Telecare 2011 Mar 11;17(4):195-198. [doi: 10.1258/jtt.2010.100602] [Medline: 21398389]

31. Chalupka S. Internet-based outpatient telerehabilitation following total knee arthroplasty. AAOHN J 2011 Mar;59(3):144-144. [doi: 10.3928/08910162-20110223-05] [Medline: 21366204]

32. Russell TG. Physical rehabilitation using telemedicine. J Telemed Telecare 2007 Jun 23;13(5):217-220. [doi: 10.1258/135763307781458886] [Medline: 17697506]

33. Hinman RS, Nelligan RK, Bennell KL, Delany C. "Sounds a Bit Crazy, But It Was Almost More Personal:" A Qualitative Study of Patient and Clinician Experiences of Physical Therapist-Prescribed Exercise For Knee Osteoarthritis Via Skype. Arthritis Care Res (Hoboken) 2017 Dec 02;69(12):1834-1844 [FREE Full text] [doi: 10.1002/acr.23218] [Medline: 28217864]

34. Chumbler NR, Quigley P, Li X, Morey M, Rose D, Sanford J, et al. Effects of Telerehabilitation on Physical Function and Disability for Stroke Patients. Stroke 2012 Aug;43(8):2168-2174. [doi: 10.1161/strokeaha.111.646943]

35. Tousignant M, Boissy P, Moffet H, Corriveau H, Cabana F, Marquis F, et al. Patients' satisfaction of healthcare services and perception with in-home telerehabilitation and physiotherapists' satisfaction toward technology for post-knee arthroplasty: an embedded study in a randomized trial. Telemed J E Health 2011 Jun;17(5):376-382. [doi: 10.1089/tmj.2010.0198] [Medline: 21492030]

36. Moffet H, Tousignant M, Nadeau S, Mérette C, Boissy P, Corriveau H, et al. Patient Satisfaction with In-Home Telerehabilitation After Total Knee Arthroplasty: Results from a Randomized Controlled Trial. Telemed J E Health 2017 Feb;23(2):80-87. [doi: 10.1089/tmj.2016.0060] [Medline: 27529575]

37. Giantomassi A, Capecci M, Benettazzo F, Iarlori S, Ferracuti F, Freddi A, et al. Training and retraining motor functions at home with the help of current technology for video games: Basis for the project. In: Ambient Assisted Living. Switzerland: Springer Nature; 2015:439-447.

38. Antón D, Nelson M, Russell T, Goñi A, Illarramendi A. Validation of a Kinect-based telerehabilitation system with total hip replacement patients. J Telemed Telecare 2015 Jun 30;22(3):192-197. [doi: 10.1177/1357633x15590019]

39. Anton D, Berges I, Bermúdez J, Goñi A, Illarramendi A. A Telerehabilitation System for the Selection, Evaluation and Remote Management of Therapies. Sensors (Basel) 2018 May 08;18(5):1459 [FREE Full text] [doi: 10.3390/s18051459] [Medline: 29738442]

40. Capecci M, Ceravolo MG, Ferracuti F, Grugnetti M, Iarlori S, Longhi S, et al. An instrumental approach for monitoring physical exercises in a visual markerless scenario: A proof of concept. J Biomech 2018 Mar 01;69:70-80. [doi: 10.1016/j.jbiomech.2018.01.008] [Medline: 29398000]

41. Da Cunha Neto JS, Reboucas Filho P, Da Silva GPF, Da Cunha Olegario NB, Duarte JBF, De Albuquerque VHC. Dynamic Evaluation and Treatment of the Movement Amplitude Using Kinect Sensor. IEEE Access 2018;6:17292-17305. [doi: 10.1109/access.2018.2811720]

42. Carregosa AA, Aguiar Dos Santos LR, Masruha MR, Coêlho MLDS, Machado TC, Souza DCB, et al. Virtual Rehabilitation through Nintendo Wii in Poststroke Patients: Follow-Up. J Stroke Cerebrovasc Dis 2018 Feb;27(2):494-498. [doi: 10.1016/j.jstrokecerebrovasdis.2017.09.029] [Medline: 29100855]

43. Karakoc Z, Colak TK, Yurdalan S. The results of adding virtual rehabilitation to standard rehabilitation program on balance and lower extremity functionality after ACL reconstruction: pilot study. Physiotherapy 2016 Nov;102:e247. [doi: 10.1016/j.physio.2016.10.309]

44. Pua Y, Clark RA, Ong P. Evaluation of the Wii Balance Board for walking aids prediction: proof-of-concept study in total knee arthroplasty. PLoS One 2015 Jan 23;10(1):e0117124 [FREE Full text] [doi: 10.1371/journal.pone.0117124] [Medline: 25615952]

45. Baltaci G, Harput G, Haksever B, Ulusoy B, Ozer H. Comparison between Nintendo Wii Fit and conventional rehabilitation on functional performance outcomes after hamstring anterior cruciate ligament reconstruction: prospective, randomized, controlled, double-blind clinical trial. Knee Surg Sports Traumatol Arthrosc 2013 Apr 29;21(4):880-887. [doi: 10.1007/s00167-012-2034-2] [Medline: 22543515]

46. Iosa M, Picerno P, Paolucci S, Morone G. Wearable inertial sensors for human movement analysis. Expert Rev Med Devices 2016 Jul 17;13(7):641-659. [doi: 10.1080/17434440.2016.1198694] [Medline: 27309490]

47. Strecher V. Internet methods for delivering behavioral and health-related interventions (eHealth). Annu Rev Clin Psychol 2007 Apr;3(1):53-76. [doi: 10.1146/annurev.clinpsy.3.022806.091428] [Medline: 17716048]

48. Jackson P. Introduction to expert systems. United States: Addison-Wesley; 1998. 
49. Rini C, Porter LS, Somers TJ, McKee DC, Keefe FJ. Retaining critical therapeutic elements of behavioral interventions translated for delivery via the Internet: recommendations and an example using pain coping skills training. J Med Internet Res 2014 Dec 19;16(12):e245 [FREE Full text] [doi: 10.2196/jmir.3374] [Medline: 25532216]

50. Shukla H, Nair S, Thakker D. Role of telerehabilitation in patients following total knee arthroplasty: Evidence from a systematic literature review and meta-analysis. J Telemed Telecare 2016 Jul 09;23(2):339-346. [doi:

10.1177/1357633x16628996]

51. Fatehi F, Bird D, Gray LC. Pubmed Searching Using Mesh Terms to Identify Randomized Controlled Trials on Telemedicine for Diabetes. J Telemed Telecare 2013 Apr 23;19(3):175-176. [doi: 10.1177/1357633x13479708]

52. Tacconelli E. Systematic reviews: CRD's guidance for undertaking reviews in health care. The Lancet Infectious Diseases 2010 Apr;10(4):226. [doi: 10.1016/s1473-3099(10)70065-7]

53. Liberati A, Altman DG, Tetzlaff J, Mulrow C, Gøtzsche PC, Ioannidis JPA, et al. The PRISMA statement for reporting systematic reviews and meta-analyses of studies that evaluate health care interventions: explanation and elaboration. PLoS Med 2009 Jul 21;6(7):e1000100 [FREE Full text] [doi: 10.1371/journal.pmed.1000100] [Medline: 19621070]

54. Kramer JF, Speechley M, Bourne R, Rorabeck C, Vaz M. Comparison of clinic- and home-based rehabilitation programs after total knee arthroplasty. Clin Orthop Relat Res 2003 May;410(410):225-234. [doi: 10.1097/01.blo.0000063600.67412.11] [Medline: 12771834]

55. Han ASY, Nairn L, Harmer AR, Crosbie J, March L, Parker D, et al. Early rehabilitation after total knee replacement surgery: a multicenter, noninferiority, randomized clinical trial comparing a home exercise program with usual outpatient care. Arthritis Care Res (Hoboken) 2015 Feb 27;67(2):196-202 [FREE Full text] [doi: 10.1002/acr.22457] [Medline: 25220488]

56. Lin F, Chen M, Li P. Influence of structured telephone follow-up on patient compliance with rehabilitation after total knee arthroplasty. PPA 2016 Mar:257. [doi: 10.2147/ppa.s102156]

57. Azma K, RezaSoltani Z, Rezaeimoghaddam F, Dadarkhah A, Mohsenolhosseini S. Efficacy of tele-rehabilitation compared with office-based physical therapy in patients with knee osteoarthritis: A randomized clinical trial. J Telemed Telecare 2017 Aug 03;24(8):560-565. [doi: 10.1177/1357633x17723368]

58. Wong YK, Hui E, Woo J. A community-based exercise programme for older persons with knee pain using telemedicine. J Telemed Telecare 2005 Sep 01;11(6):310-315. [doi: 10.1258/1357633054893346] [Medline: 16168168]

59. Tousignant M, Boissy P, Corriveau H, Moffet H, Cabana F. In-home telerehabilitation for post-knee arthroplasty: a pilot study. Int J Telerehabil 2009 Sep 04;1(1):9-16 [FREE Full text] [doi: 10.5195/ijt.2009.5997] [Medline: 25945158]

60. Moffet H, Tousignant M, Nadeau S, Mérette C, Boissy P, Corriveau H, et al. In-Home Telerehabilitation Compared with Face-to-Face Rehabilitation After Total Knee Arthroplasty. The Journal of Bone and Joint Surgery-American Volume 2015;97(14):1129-1141. [doi: 10.2106/jbjs.n.01066]

61. Boissy P, Tousignant M, Moffet H, Nadeau S, Brière S, Mérette C, et al. Conditions of Use, Reliability, and Quality of Audio/Video-Mediated Communications During In-Home Rehabilitation Teletreatment for Postknee Arthroplasty. Telemed J E Health 2016 Aug;22(8):637-649. [doi: 10.1089/tmj.2015.0157] [Medline: 26958932]

62. Bini S, Mahajan J. Clinical outcomes of remote asynchronous telerehabilitation are equivalent to traditional therapy following total knee arthroplasty: A randomized control study. J Telemed Telecare 2016 Jul 09;23(2):239-247. [doi: $10.1177 / 1357633 \times 16634518]$

63. Doiron-Cadrin P, Kairy D, Vendittoli P, Lowry V, Poitras S, Desmeules F. Feasibility and preliminary effects of a tele-prehabilitation program and an in-person prehablitation program compared to usual care for total hip or knee arthroplasty candidates: a pilot randomized controlled trial. Disabil Rehabil 2020 Apr 13;42(7):989-998. [doi: 10.1080/09638288.2018.1515992] [Medline: 30638076]

64. Eisermann U, Haase I, Kladny B. Computer-aided multimedia training in orthopedic rehabilitation. Am J Phys Med Rehabil 2004 Sep;83(9):670-680. [doi: 10.1097/01.phm.0000137307.44173.5d] [Medline: 15314531]

65. Piqueras M, Marco E, Coll M, Escalada F, Ballester A, Cinca C, et al. Effectiveness of an interactive virtual telerehabilitation system in patients after total knee arthoplasty: a randomized controlled trial. J Rehabil Med 2013 Apr;45(4):392-396 [FREE Full text] [doi: 10.2340/16501977-1119] [Medline: 23474735]

66. Ayoade M, Baillie L. A novel knee rehabilitation system for the home. New YorkNYUnited States: Association for Computing Machinery; 2014 Presented at: Proceedings of the 32nd annual ACM conference on Human factors in computing systems - CHI '14; 26 Apr - 1 May; Toronto Ontario Canada p. 2521-2530. [doi: 10.1145/2556288.2557353]

67. Correia FD, Nogueira A, Magalhães I, Guimarães J, Moreira M, Barradas I, et al. Home-based Rehabilitation With A Novel Digital Biofeedback System versus Conventional In-person Rehabilitation after Total Knee Replacement: a feasibility study. Sci Rep 2018 Jul 26;8(1):11299 [FREE Full text] [doi: 10.1038/s41598-018-29668-0] [Medline: 30050087]

68. Correia FD, Nogueira A, Magalhães I, Guimarães J, Moreira M, Barradas I, et al. Medium-Term Outcomes of Digital Versus Conventional Home-Based Rehabilitation After Total Knee Arthroplasty: Prospective, Parallel-Group Feasibility Study. JMIR Rehabil Assist Technol 2019 Feb 28;6(1):e13111 [FREE Full text] [doi: 10.2196/13111] [Medline: 30816849]

69. Argent R, Slevin P, Bevilacqua A, Neligan M, Daly A, Caulfield B. Wearable Sensor-Based Exercise Biofeedback for Orthopaedic Rehabilitation: A Mixed Methods User Evaluation of a Prototype System. Sensors (Basel) 2019 Jan 21;19(2):432 [FREE Full text] [doi: 10.3390/s19020432] [Medline: $\underline{\text { 30669657] }}$ 
70. Ramkumar PN, Haeberle HS, Ramanathan D, Cantrell WA, Navarro SM, Mont MA, et al. Remote Patient Monitoring Using Mobile Health for Total Knee Arthroplasty: Validation of a Wearable and Machine Learning-Based Surveillance Platform. J Arthroplasty 2019 Oct;34(10):2253-2259. [doi: 10.1016/j.arth.2019.05.021] [Medline: $\underline{31128890]}$

71. Eichler S, Salzwedel A, Rabe S, Mueller S, Mayer F, Wochatz M, et al. The Effectiveness of Telerehabilitation as a Supplement to Rehabilitation in Patients After Total Knee or Hip Replacement: Randomized Controlled Trial. JMIR Rehabil Assist Technol 2019 Nov 07;6(2):e14236 [FREE Full text] [doi: 10.2196/14236] [Medline: $\underline{31697239}$ ]

72. Prvu Bettger J, Green C, Holmes D, Chokshi A, Mather RC, Hoch BT, et al. Effects of Virtual Exercise Rehabilitation In-Home Therapy Compared with Traditional Care After Total Knee Arthroplasty: VERITAS, a Randomized Controlled Trial. J Bone Joint Surg Am 2020 Jan 15;102(2):101-109. [doi: 10.2106/JBJS.19.00695] [Medline: $\underline{31743238]}$

73. Kuether J, Moore A, Kahan J, Martucci J, Messina T, Perreault R, et al. Telerehabilitation for Total Hip and Knee Arthroplasty Patients: A Pilot Series with High Patient Satisfaction. HSS J 2019 Oct 21;15(3):221-225 [FREE Full text] [doi: 10.1007/s11420-019-09715-w] [Medline: $\underline{31624476}$ ]

74. Chughtai M, Newman J, Sultan A, Khlopas A, Navarro SM, Bhave A, et al. The Role of Virtual Rehabilitation in Total Knee and Hip Arthroplasty. Surg Technol Int 2018 Jun 01;32:299-305. [Medline: 29566421]

75. Bossen D, Veenhof C, Dekker J, de Bakker D. The usability and preliminary effectiveness of a web-based physical activity intervention in patients with knee and/or hip osteoarthritis. BMC Med Inform Decis Mak 2013 May 28;13(1):61 [FREE Full text] [doi: 10.1186/1472-6947-13-61] [Medline: 23714120]

76. Bossen D, Buskermolen M, Veenhof C, de Bakker D, Dekker J. Adherence to a web-based physical activity intervention for patients with knee and/or hip osteoarthritis: a mixed method study. J Med Internet Res 2013 Oct 16;15(10):e223 [FREE Full text] [doi: 10.2196/jmir.2742] [Medline: 24132044]

77. Bossen D, Veenhof C, Van Beek KE, Spreeuwenberg PM, Dekker J, De Bakker DH. Effectiveness of a web-based physical activity intervention in patients with knee and/or hip osteoarthritis: randomized controlled trial. J Med Internet Res 2013 Nov 22;15(11):e257 [FREE Full text] [doi: 10.2196/jmir.2662] [Medline: 24269911]

78. Rini C, Porter LS, Somers TJ, McKee DC, DeVellis RF, Smith M, et al. Automated Internet-based pain coping skills training to manage osteoarthritis pain: a randomized controlled trial. Pain 2015 May;156(5):837-848 [FREE Full text] [doi: 10.1097/j.pain.0000000000000121] [Medline: 25734997]

79. Kim TWB, Gay N, Khemka A, Garino J. Internet-Based Exercise Therapy Using Algorithms for Conservative Treatment of Anterior Knee Pain: A Pragmatic Randomized Controlled Trial. JMIR Rehabil Assist Technol 2016 Dec 14;3(2):e12 [FREE Full text] [doi: 10.2196/rehab.5148] [Medline: 28582256]

80. Bennell KL, Nelligan R, Dobson F, Rini C, Keefe F, Kasza J, et al. Effectiveness of an Internet-Delivered Exercise and Pain-Coping Skills Training Intervention for Persons With Chronic Knee Pain. Ann Intern Med 2017 Feb 21;166(7):453. [doi: $10.7326 / \mathrm{m} 16-1714]$

81. Lawford BJ, Hinman RS, Kasza J, Nelligan R, Keefe F, Rini C, et al. Moderators of Effects of Internet-Delivered Exercise and Pain Coping Skills Training for People With Knee Osteoarthritis: Exploratory Analysis of the IMPACT Randomized Controlled Trial. J Med Internet Res 2018 May 09;20(5):e10021. [doi: 10.2196/10021] [Medline: 29743149]

82. Bossen D, Kloek C, Snippe HW, Dekker J, de Bakker D, Veenhof C. A Blended Intervention for Patients With Knee and Hip Osteoarthritis in the Physical Therapy Practice: Development and a Pilot Study. JMIR Res Protoc 2016 Feb 24;5(1):e32 [FREE Full text] [doi: 10.2196/resprot.5049] [Medline: 26912378]

83. de Vries HJ, Kloek CJ, de Bakker DH, Dekker J, Bossen D, Veenhof C. Determinants of Adherence to the Online Component of a Blended Intervention for Patients with Hip and/or Knee Osteoarthritis: A Mixed Methods Study Embedded in the e-Exercise Trial. Telemed J E Health 2017 Dec;23(12):1002-1010. [doi: 10.1089/tmj.2016.0264] [Medline: 28525310]

84. Kloek CJJ, van Dongen JM, de Bakker DH, Bossen D, Dekker J, Veenhof C. Cost-effectiveness of a blended physiotherapy intervention compared to usual physiotherapy in patients with hip and/or knee osteoarthritis: a cluster randomized controlled trial. BMC Public Health 2018 Aug 31;18(1):1082 [FREE Full text] [doi: 10.1186/s12889-018-5975-7] [Medline: 30170586]

85. Kloek CJ, Bossen D, de Vries HJ, de Bakker DH, Veenhof C, Dekker J. Physiotherapists' experiences with a blended osteoarthritis intervention: a mixed methods study. Physiother Theory Pract 2020 May 28;36(5):572-579. [doi: 10.1080/09593985.2018.1489926] [Medline: 29952687]

86. Kloek C, Bossen D, Spreeuwenberg P, Dekker J, de Bakker DH, Veenhof C. Effectiveness of a Blended Physical Therapist Intervention in People With Hip Osteoarthritis, Knee Osteoarthritis, or Both: A Cluster-Randomized Controlled Trial. Phys Ther 2018 Jul 01;98(7):560-570 [FREE Full text] [doi: 10.1093/ptj/pzy045] [Medline: 29788253]

87. Ramkumar PN, Haeberle HS, Navarro SM, Sultan AA, Mont MA, Ricchetti ET, et al. Mobile technology and telemedicine for shoulder range of motion: validation of a motion-based machine-learning software development kit. J Shoulder Elbow Surg 2018 Jul;27(7):1198-1204. [doi: 10.1016/j.jse.2018.01.013] [Medline: 29525490]

88. Eichler S, Rabe S, Salzwedel A, Müller S, Stoll J, Tilgner N, ReMove-It study group. Effectiveness of an interactive telerehabilitation system with home-based exercise training in patients after total hip or knee replacement: study protocol for a multicenter, superiority, no-blinded randomized controlled trial. Trials 2017 Sep 21;18(1):438 [FREE Full text] [doi: 10.1186/s13063-017-2173-3] [Medline: 28934966]

89. Microsoft. Kinect for Windows SDK 2.0. 2014. URL: https://www.microsoft.com/en-us/download/details.aspx?id=44561 [accessed 2020-06-30] 
90. Veenhof C, Köke AJA, Dekker J, Oostendorp RA, Bijlsma JWJ, van Tulder MW, et al. Effectiveness of behavioral graded activity in patients with osteoarthritis of the hip and/or knee: A randomized clinical trial. Arthritis Rheum 2006 Dec 15;55(6):925-934 [FREE Full text] [doi: 10.1002/art.22341] [Medline: 17139639]

91. Clemensen J, Rothmann MJ, Smith AC, Caffery LJ, Danbjorg DB. Participatory design methods in telemedicine research. J Telemed Telecare 2016 Dec 27;23(9):780-785. [doi: 10.1177/1357633x16686747]

92. Li L, Gan Y, Zhang L, Wang Y, Zhang F, Qi J. The effect of post-discharge telephone intervention on rehabilitation following total hip replacement surgery. International Journal of Nursing Sciences 2014 Jun;1(2):207-211. [doi: 10.1016/j.ijnss.2014.05.005]

93. Hørdam B, Sabroe S, Pedersen P, Mejdahl S, Søballe K. Nursing intervention by telephone interviews of patients aged over 65 years after total hip replacement improves health status: a randomised clinical trial. Scand J Caring Sci 2010 Mar;24(1):94-100. [doi: 10.1111/j.1471-6712.2009.00691.x] [Medline: 19422632]

94. Russell TG, Buttrum P, Wootton R, Jull GA. Rehabilitation after total knee replacement via low-bandwidth telemedicine: the patient and therapist experience. J Telemed Telecare 2004 Dec 02;10 Suppl 1(1_suppl):85-87. [doi: 10.1258/1357633042614384] [Medline: 15603622]

95. Lemaire E, Boudrias Y, Greene G. Low-bandwidth, Internet-based videoconferencing for physical rehabilitation consultations. J Telemed Telecare 2001;7(2):82-89. [doi: 10.1258/1357633011936200] [Medline: 11331045]

96. Cabana F, Boissy P, Tousignant M, Moffet H, Corriveau H, Dumais R. Interrater agreement between telerehabilitation and face-to-face clinical outcome measurements for total knee arthroplasty. Telemed J E Health 2010 Apr;16(3):293-298. [doi: 10.1089/tmj.2009.0106] [Medline: 20406116]

97. Russell T, Jull G, Wootton R. Can the Internet be used as a medium to evaluate knee angle? Manual Therapy 2003 Nov;8(4):242-246. [doi: 10.1016/s1356-689x(03)00016-x]

98. Russell TG, Wootton R, Jull GA. Physical outcome measurements via the Internet: reliability at two Internet speeds. J Telemed Telecare 2002 Dec 02;8 Suppl 3(6):50-52. [doi: 10.1258/13576330260440853] [Medline: 12537905]

99. Russell TG, Buttrum P, Wootton R, Jull GA. Internet-Based Outpatient Telerehabilitation for Patients Following Total Knee Arthroplasty. The Journal of Bone and Joint Surgery-American Volume 2011;93(2):113-120. [doi: 10.2106/jbjs.i.01375]

100. Pérez-Manchón D, Caramés-Sánchez C, Pfang B. An asynchronous telemedicine program: Three years' experience with African patients treated in Spain. J Telemed Telecare 2016 Jul 03;23(5):558-560. [doi: 10.1177/1357633x16658159]

101. Chen K, Chen P, Liu K, Chan C. Wearable sensor-based rehabilitation exercise assessment for knee osteoarthritis. Sensors (Basel) 2015 Feb 12;15(2):4193-4211 [FREE Full text] [doi: 10.3390/s150204193] [Medline: 25686308]

102. Han S, Xie M, Chien C, Cheng Y, Tsao C. Using MEMS-based inertial sensor with ankle foot orthosis for telerehabilitation and its clinical evaluation in brain injuries and total knee replacement patients. Microsyst Technol 2015 Feb 3;22(3):625-634. [doi: $10.1007 / \mathrm{s} 00542-015-2439-1]$

103. Kobsar D, Osis S, Boyd J, Hettinga B, Ferber R. Wearable sensors to predict response to a hip strengthening exercise intervention in patients with knee osteoarthritis. Osteoarthritis and Cartilage 2017 Apr;25:S23-S24. [doi:

10.1016/j.joca.2017.02.052]

104. Naeemabadi M, Dinesen B, Najafi S, Thogersen M, Hansen J. Feasibility of employing AHRS algorithms in the real-time estimation of sensor orientation using low-cost and low sampling rate wearable sensors in IoT application. 2018 Presented at: 2018 IEEE 8th International Conference on Consumer Electronics - Berlin (ICCE-Berlin); 2 - 5 Sep 2018; Berlin, Germany p. 1-6. [doi: 10.1109/icce-berlin.2018.8576239]

105. Naeemabadi M, Dinesen B, Andersen O, Najafi S, Hansen J. Evaluating Accuracy and Usability of Microsoft Kinect Sensors and Wearable Sensor for Tele Knee Rehabilitation after Knee Operation. 2018 Presented at: Proceedings of the 11th International Joint Conference on Biomedical Engineering Systems and Technologies; 19-21 Jan; Funchal, Portegual p. 128-135. [doi: 10.5220/0006578201280135]

106. Milgram P, Kishino F. A taxonomy of mixed reality visual displays. IEICE TRANSACTIONS on Information and Systems 1994 Dec 25;77:1321-1329.

\author{
Abbreviations \\ 9DOF: 9 degrees of freedom \\ CINAHL: Cumulative Index to Nursing and Allied Health Literature \\ PEDro: Physiotherapy Evidence Database \\ PRISMA: Preferred Reporting Items for Systematic Reviews and Meta-Analyses \\ MeSH: medical subject heading \\ RCT: randomized controlled trial
}


Edited by G Eysenbach; submitted 09.11.19; peer-reviewed by D Kairy, C Snoswell; comments to author 09.12.19; revised version received 16.05.20; accepted 14.06.20; published 21.07.20

Please cite as:

Naeemabadi M, Fazlali H, Najafi S, Dinesen B, Hansen J

Telerehabilitation for Patients With Knee Osteoarthritis: A Focused Review of Technologies and Teleservices

JMIR Biomed Eng 2020;5(1):e16991

URL: http://biomedeng.jmir.org/2020/1/e16991/

doi: 10.2196/16991

PMID:

CMReza Naeemabadi, Hesam Fazlali, Samira Najafi, Birthe Dinesen, John Hansen. Originally published in JMIR Biomedical Engineering (http://biomedeng.jmir.org), 21.07.2020. This is an open-access article distributed under the terms of the Creative Commons Attribution License (https://creativecommons.org/licenses/by/4.0/), which permits unrestricted use, distribution, and reproduction in any medium, provided the original work, first published in JMIR Biomedical Engineering, is properly cited. The complete bibliographic information, a link to the original publication on http://biomedeng.jmir.org/, as well as this copyright and license information must be included. 